\title{
History as a Mirror: Research on the Development of Contemporary Chinese Art Colleges
}

\author{
Yurong $\mathrm{Ma}^{1, *}$ \\ ${ }^{1}$ Faculty of Innovation and Design, City University of Macau, Macau 999078, China \\ *Corresponding author. Email: 739123477@qq.com
}

\begin{abstract}
At the end of the Qing Dynasty and the beginning of the Ming Dynasty, China was in the wave of learning Western thought and technology, and was gradually influenced by the western learning. During a period of time, schools and courses featuring Chinese art education emerged. Under the irreversible trend of economic globalization, the development of science and technology and the boundaries of art have been broken, and the integration of the two has brought new experiences and new results to art schools and society. The contemporary development of socialist art colleges with Chinese characteristics and the increase in the allocation of innovative art majors have positive thinking significance for the cultivation of true talents, good virtue and high-grade professional art talents in China.
\end{abstract}

\section{Keywords: contemporary, Chinese Art Academy, art major, science and technology}

\section{INTRODUCTION}

Xi Jinping clearly stated in the symposium on literary work: "Literature and art are advance bugle of the era, a representative of the era, and a leading spirit of the era." [1] With Chinese characteristics Socialism entering a new era, the cultural development has also led to a new historical orientation, but all this is rooted in the inheritance of the Chinese aesthetic spirit and excellent traditional culture. As the "Jiu Tang Shu, Wei Zheng Biography" said: "Bronze as a mirror, you can dress up; with ancient as a mirror, you can know the rise and fall; with people as a mirror, you can see the gains and losses." [2] The exploration of the beginning and the establishment of professional courses has played a role in reference and comparison to a certain extent for the development of art colleges and the newly added art majors, with inestimable historical value. Changes in the field of Chinese fine arts in the new era have an indelible impact to a series of important judgments and scientific expositions concerning the law of development of socialist literature and art, such as the Guiding Ideology for the Study of Literature and Art, the Value of Literature and Art, the Mission of Literature and Art, the Relationship between Literature and Art and the People, Era, Politics, Economy, Creation and Criticism, the Party 's Leadership in Literature and Art, etc.

\section{THE DEVELOPMENT OF ART COLLEGES}

\section{A. Tracing the origin of the rise of art colleges}

Chinese art in the twentieth century was strike by Western culture. At that time, China's feudal society was gradually collapsing, and the society was undergoing tremendous changes. Whether it is the result of the modern Western industrial revolution, or the achievements of political culture. They are deeply concerned by the intellectual revolutionaries. compared to decadent feudal system, backward productivity, ancient painting characteristics, western Anatomy, Modeling Techniques, Realism and other artistic techniques have a strong attraction for intellectuals. It was not the painters and historians who first proposed changes to this phenomenon, but a series of explorations carried out by thinkers and revolutionaries in China.

When the Chinese fine arts are in urgent need of reform, Kang Youwei (styled name Guangsha, pseudonym Chang $\mathrm{Su}$ ) mentioned in the "Chinese Paintings in Wanmu Caotang": "The reason why modern Chinese art painting collapsed is the theory of painting skill is fault."[3] Next year, this article was published in the "China Art Newspaper". Compared with the slogan he proposed in 1905, the article elaborated on Kang Youwei's proposition of reform in art. Respecting the creation of paintings requires realism and depreciated the method of freehand brushwork; Cai Yuanpei (style name Heqing, jiemin) pointed out in "Aesthetic Education Instead of 
Religion" that only religion can be replaced by aesthetic education, and art cannot replace religion. After the founding of New China, aesthetic education was included in the national education system; in 1919, Liu Haili mentioned it in "Necessary Points in Painting". European and American painting "realism", "realismnatural-positive-true-beauty-the development of automatic ability" Chinese painting follows: "imitationmandatory-negative-false beauty-cultivation depends on habit".

On the way of the revolution in the art revolution, Liang Qichao mentioned in the "General Reform" that "the foundation of the reform is to educate talents; the rise of talents is to open schools; the establishment of schools is to reform the imperial examinations." [4] He believes that learning from modern west is the foundation of the reform, and the influence of the west on the art field is first reflected in the art schools that have been established all over the country. They have adopted the western mode of subject education and took the lead in breaking the previous teaching method through teachers 'apprenticeship and family, and the internal transmission situation of individual comprehension and tracing of the ancient people's pen pattern have had an unprecedented impact on traditional art. In the 32nd year of Guangxu, the first drawing manual class in Chinese colleges and universities was run by the Governor of Liangjiang. The school is Liangjiang Normal School located in Nanjing. In addition to traditional Chinese painting, there are also Western painting classes such as oil painting, watercolor, charcoal, etc. After the early famous art educator Li Shutong returned from studying in Japan, he also taught music lessons and painting lessons in the school. The Liangjiang Normal School is one of the earliest normal school in modern China. After the Revolution of 1911, various schools such as the Beijing Teachers 'College and other schools also set up specialized courses in drawing and handwork. There are a large number of schools featuring art education or schools offering art education courses. At that time, China's social level was backward, wars were struggling, and funding constraints were serious. which reflected the difficulty of starting art education, but it still dared not to give up hard work and laid the foundation for the development of new art in China.

\section{B. Vigorous development of art colleges in the new era}

Since the founding of New China, the vigorous development of art education has ushered in the dawn of New China, bringing together and creating a large number of well-known artists and art educators at civil and abroad. The predecessor of the Central Academy of Fine Arts was born in 1918, the first national academy of fine arts education-National Academy of Fine Arts, has ushered in the centenary of the establishment of the school, $\mathrm{Xu}$ Beihong is the first principal. Taking this centuries-old glorious school as a research case, it is typical. Central Academy of Fine Arts, the head of the eight major academies, is the beginning of Chinese modern art education and the earliest art school system. It is an important microcosm of the developments of China's modern art and art education.

Talent cultivation is recognized as an advanced model among professional colleges in Central America. As a benchmark of domestic art and a world-class prestigious school with advanced academic thinking, judging from the university subject courses, calligraphy, architecture and humanities have been established earlier. There are 10 disciplines, including 20 undergraduate majors, including the School of Experimental Art, School of Urban Design, School of Art Management and Education, and School of Continuing Education. The elite of the teaching staff gathered before the founding of New China, such as Chen Shizeng, Qi Baishi, Huang Binhong, Jiang Zhaohe, Ye Qianyu, Fu Xinshe, Wu Jingting, etc. After the founding of New China, Li Zongjin, Hou Yimin, Zhan Jianjun, Jin Shangyi and other experts gathered. The "mentor studio" system is the most distinctive in the process of training students. Under the condition of maintaining the quality through the teacher's "teaching, assist, and help", there are currently more than 1,000 graduates every year. As the only higher art school directly under the Ministry of Education in China, it has always upheld the philosophy of "focusing on reality and serving the people".

In the last century, Chinese art schools introduced the Soviet Cheschakov system, and the teaching method of Cheschakov system sketch was more influential in China in the 1950s and 1960s. This basic teaching mode was deeply influenced by Western aesthetics. influences. After the reform and opening up, the previous system is no longer applicable to the rapid development trend in the new era, so the American education system has also undergone corresponding reforms on the basis of its general unchanged. China 's comprehensive universities and art professional colleges have delivered a large number of quality art talents to the society. But it is undeniable that the art education in colleges and universities is in line with the times. At present, there are still some areas that need to be improved and improved, such as too rigid study of theoretical knowledge, thus neglecting skills training or lack of out-of-town sketching and going to museums and other local investigations; In the expansion of colleges and universities, talents are not only piled up and the training objectives are ambiguous, but there is also waste in terms of training.

In the journey of the new era, it is necessary to take Chairman Xi Jinping's literary and artistic ideas as the guide to effectively implement the artistic creation and theoretical research of teachers and students. Building a 
first-class world-class art college with Chinese characteristics, with equal emphasis on inheritance and innovation, being socially oriented, building a "peoplerooted" education model is not only a slogan, it will help to awaken the creativity of students, cultivate creative thinking, and enhance Student humanities. The art revolution in the 20th century and the establishment of art academies have accumulated for the flourishing development of art academies in the 21 st century, and have cultivated batches of art "specialists" for China. After the reform and opening up, the country strongly supports and is rooted in China's basic national conditions. The advanced school concept, rich teaching content, comprehensive art professional curriculum, excellent teacher professional quality, and perfect education and teaching practices the torrent of torrents is improving day after day, creating an art education system adapted to China's national conditions.

\section{THE RISE OF NEW ART MAJORS IN THE NEW ERA}

\section{A. The combination of art and science}

Major universities and museums have conducted many special academic exchange lectures. Such as the Science and Technology Festival held in Shanghai, 2017, the "The Fusion of Science And Art- Exhibition of T. D. Lee Science And Art Lecture Fund" which is jointly organized by Shanghai Jiaotong University and Shanghai Science and Technology Museum; In 2018, Guangdong Museum of Art launched a series of public education activities "When technology meets art"; In 2019, Jiageng College of Xiamen University invited Professor Furukata Masahiko of Musashino Art University who was a pioneering artist in Japan engaged in interactive art creation earlier, bringing lectures on "art and technology" to teachers and students of the art design department. In 2020, the School of Industrial Design held a lecture on "Core of Art and Technology". Lu Xiaobo, Dean of the Academy of Fine Arts of Tsinghua University, put forward the view that "design is driven by humanity and scientific spirit to drive innovation". Each historical period has a certain art paradigm, forming a certain mainstream direction and artistic trend.

In order to deliver new talents and new needs of the new era to the IT industry, film and television animation companies, media and media art institutions and other companies or research institutes, cultivate professional advanced professional innovative art talents with modern exhibition knowledge and internationalization, education in 2012 The bureau promulgated the undergraduate professional catalogue of colleges and universities to set Art and Science as a new major, the professional code is $130509 \mathrm{~T}$, the subject category is arts, and the bachelor of arts is awarded. At present, 52 colleges and universities including Tsinghua University, The Guangzhou Academy of Fine Arts, Xiamen University of Technology, and Shanghai University of Engineering Science have opened art and Science majors. Among them, the representative universities are the Communication University of China and its Nanguang College. The society is in an era of rapid change. The rapid development of big data, artificial intelligence, Internet of Things and other technologies requires students to have strong innovative thinking ability, performance communication ability and creative realization ability in the context of digital technology. To have the ability to communicate and communicate with each other, in response to the new needs of the information age, cross-disciplinary team collaborative innovation can be carried out.

Major universities and museums have conducted special academic exchange lectures. In 2017 Shanghai Science and Technology Festival, the "Communication of Science and Art- Zhengdao Li Science and Art Lecture Fund Works Exhibition" jointly organized by Shanghai Jiaotong University and Shanghai Science and Technology Museum; In 2018, Guangdong Museum of Art launched a series of public education activities "When technology meets art"; In 2019, Xiamen University Tan Kah Kee College invited Professor Furukata Masahiko of the School of Modeling, Musashino Art University, Japan. He was a pioneering artist in Japan engaged in interactive art creation earlier, bringing lectures on "art and technology" to teachers and students of the art design department; In 2020, the School of Industrial Design held a lecture on "Core of Art and Technology". Xiaobo Lu, Dean of the Academy of Fine Arts of Tsinghua University, put forward the view that "design is driven by humanity and scientific spirit to drive innovation". Each historical period has a certain art paradigm, forming a certain mainstream direction and artistic trend.

\section{B. Other science and art blending cases}

Science and art have many similarities in nature, and the combination of the two is also the main theme of the new era, but at the same time there are certain differences in its development process. Science mainly uses abstract thinking, emphasizing rational factors. Virtual technology has created an unprecedented cultural environment and means of communication for art. The most obvious is film, VR technology, and 3D technology; art mainly uses image thinking, emphasizing emotional factors, painting, poetry and other expressions, evoking people's subconscious emotions.

In the long development process of art, the rapid iteration of modern science and technology has caused subversive changes in all aspects of art creation 
concepts, expressions and theoretical interpretations. The special exhibition of the Chinese Art Palace located in Shanghai displays the great treasures in the history of Chinese art, "Riverside Scene at Qingming Festival ", the only reserved item in the China National Pavilion for World Expo in the form of multimedia. This custom painting depicts the prosperous scene of Bianjing, the capital of Song Dynasty. Which is painted on the hundred-meter-long volume, reappeared through the secular features of day and night, be almost lifelike in appearance. The whole venue creates a scene immersion atmosphere, which fully mobilizes the audience's senses, brings visual feast and brand-new experience, cross-media interaction and information, the overlap of virtual and reality, makes people feel like walking in the river of time and painting. There is another painting, " Thousands miles of mountains and rivers " in China's top ten masterpieces — " The first masterpiece of green landscape painting in the past 900 years " is exhibited at the Macau Art Museum in the form of digital as " Thousands miles of mountains and rivers 3.0", with a total length of 35 meters, has a Dynamic digital long volume with real-time layered rendering core technology and time transformation system, According to the four themes of "walking, sightseeing, viewing and living", the detailed depiction of the original work is presented in high-definition, so that the figures and landscapes described in the original painting can be "moved" and the audience can experience the beauty of the mountains and rivers. Through digital multimedia, interactive experience, space furnishings, physical display and other different presentation methods, it fully displays the aesthetic conception contained in the " Thousands miles of mountains and rivers ", It not only conveys the philosophy of the unity of heaven and man in this masterpiece, but also causes the audience to think about the harmony between man and nature, man and society, man and heart, and promotes the inheritance, development and reconstruction of traditional culture in the new era.

Post-production of TV series promo for " Eternal Love ", "Illusion of Time and Space" immersive concert production design of Zhejiang Conservatory of Music, opening ceremony of "Create@Alibaba Cloud Startup Contest", works of " The Night of Haze "and the creative projection of the "Opening ceremony of Zhujie Street " in Hefei, Anhui, 2017, all shows the creative process and reflections on the integration of culture and technology. Facing the future, we should attach equal importance to the value of nature and humanity, integrate science and art, inherit and innovate, globalize and localize simultaneously.

\section{CONCLUSION}

Art colleges and universities have always been responsible for cultivating art professionals in the new era. Standing on a new historical position in the development of literature and art, and taking history as a mirror, we can think deeply about art schools under the background of modern society, so as to carry out a new round of exploration and reform. In the new era, China's fine arts education has the characteristics of wide coverage and rich professional types. Degrees are also divided into bachelor's degree, master's degree, and doctorate. Looking back on the old and new changes of art colleges, from a simple curriculum structure to the establishment of new and innovative majors, and the establishment of compulsory courses and elective courses; from the two independent fields of science and art history, to the combination of the two , Derived a series of innovative professional and artistic works; from the establishment of the fine arts academies to the gathering of contemporary colleges and universities, cultivate artistic talents with the characteristics of the times, create masters of German art and double sweets, and add icing to the Chinese cultural cause .

General Secretary Xi Jinping emphasized at the literary symposium: "The highest state of art is to be inviting, let people's souls be baptized, and let people discover beauty. It is necessary to pass the values of truth, goodness and beauty through literary and artistic works, and guide people to strengthen their moral judgment. And a sense of moral honor, longing for and pursuing a life that emphasizes morality, respects morality, and abides by morality."[5] "Culture rejuvenates the country, promotes prosperity, and culture strengthens the people."[6] As an extremely active part of cultural construction, literature and art should deserve to build a socialist cultural power. As an important mission, the art education system will have more Chinese characteristics when facing the future. The development of art in the new era is still facing many problems. This calls on the majority of artists to firmly create and cast the unique peaks of literature and art in this new era with the Chinese people's unique thoughts, emotions, and aesthetics. The building of a socialist cultural powerhouse contributes wisdom and strength.

\section{References}

[1] "Finding the Position and Position of Literary and Artistic Work in the New Era" [N]. Guangming.com, July 31, 2018.

[2] Yun Donghui. With books as a mirror, you can manage politics — Read "A mirror for politician" [J]. China Book Review, 1999 (10): 57-58.

[3] Kang Youwei. Excerpts from Kang Youwei's Catalogue of Paintings in Wanmu Caotang [J]. Friends of Calligraphy, 1997 (04): 26-33.

[4] Shi Jizhong. Yan Xiu: Pioneer of China's Education Reform [J]. People's Congress Forum, 2011, 000 (010): P.53-54.

[5] "Xi Jinping presided over the holding of a symposium on literary and artistic work to emphasize: adhere to the people- 
centered creative direction" [N]. People's Net-People's Daily, October 16, 2014.

[6] Chen Zehuan. Times and nationality: the academic construction of cultural self-confidence [J]. Journal of Shenzhen University: Humanities and Social Sciences Edition, 2018, v.35; No.172 (04): 5-11 